\title{
Pengaruh Lingkungan Tempat Tinggal dan Motivasi Belajar terhadap Hasil Belajar Peserta Didik Kelas VI di SD Negeri 1 Bakauheni
}

\author{
Amrina Izzatika ${ }^{1 *}$, Ika Wulandari Utaminingtyas ${ }^{2}$ \\ ${ }^{1}$ Pendidikan Guru Sekolah Dasar, Universitas Lampung \\ ${ }^{2}$ Pendidikan Guru Sekolah Dasar, Universitas Lampung \\ E-mail: amrina.izzatika@fkip.unila.ac.id
}

\begin{abstract}
The issue in this research is there are is less supportive and the learning motivation of students is low, and that causing low students learning outcomes learning. The purpose of this study was to obtain empirical results about the effect of the living environment and learning motivation on the learning outcomes of students class $6^{\text {th }}$ at SD Negeri 1 Bakauheni. Type of research that is used by the researchist is the quantitative analysis. The method is ex-post-facto, by using the total sampling, which the subject is the students class $6^{\text {th }}$. The data collecting method is using the questionnaire instrument and mid-semester asessment documentation. Data analysis is using simple linear regression. The results showed that: 1. The living environment had no effect on the learning outcomes of students class $6^{\text {th }}$ at $S D$ Negeri 1 Bakauheni, 2. Motivation to learn had effect on the learning outcomes of students class $6^{\text {th }}$ at SD Negeri 1 Bakauheni.
\end{abstract}

Keywords: living environment, learning motivation, learning outcomes

Abstrak: Masalah dalam penelitian ini adalah lingkungan tempat tinggal yang kurang mendukung dan motivasi belajar peserta didik yang rendah sehingga menyebabkan rendahnya hasil belajar peserta didik. Tujuan penelitian ini adalah untuk memperoleh hasil empiris tentang pengaruh lingkungan tempat tinggal dan motivasi belajar terhadap hasil belajar peserta didik kelas VI SD Negeri 1 Bakauheni. Jenis penelitian yang digunakan adalah penelitian kuantitatif. Metode penelitian yang digunakan peneliti adalah metode ex- post-facto. Teknik sampel yang digunakan adalah total sampling, dengan subjek penelitian peserta didik kelas VI. Metode pengumpulan data menggunakan instrumen angket dan dokumentasi hasil nilai. Analisis data menggunakan regresi linier sederhana. Hasil penelitian menunjukkan bahwa: 1. Lingkungan tempat tinggal tidak ada pengaruh terhadap hasil belajar peserta didik kelas VI di SD Negeri 1 Bakauheni, 2. Motivasi belajar ada pengaruh terhadap hasil belajar peserta didik kelas VI SD Negeri 1 Bakauheni.

Kata Kunci: lingkungan tempat tinggal, motivasi belajar, hasil belajar

\section{PENDAHULUAN}

Kualitas pendidikan dapat dilihat dari 2 hal, yaitu kualitas proses dan kualitas produk. Pendidikan dikatakan berkualitas proses apabila dalam proses pembelajaran dapat berlangsung secara efektif dan peserta didik mengalami pembelajaran yang bermakna. Pendidikan dikatakan berkualitas produk apabila peserta didik menunjukan tingkat penguasan tinggi terhadap tugas-tugas belajar sesuai dengan sasaran dan tujuan pendidikan. Hal ini dilihat pada hasil belajar yang dinyatakan dalam proses akademik. 
Jude et al. (2014: 107) menjelaskan bahwa hasil belajar merupakan indikator untuk mengukur efek belajar peserta didik serta hal utama untuk evaluasi kualitas pengajaran. Hasil belajar dibidang pendidikan adalah hasil dari pengukuran terhadap peserta didik yang meliputi faktor kognitif, afektif dan psikomotorik kemudian dinyatakan dalam bentuk simbol, huruf maupun kalimat. Hasil belajar kognitif matematika peserta didik kelas VI di salah satu SD Negeri yang terdapat di Kecamatan Bakauheni tahun ajaran 2020/2021 masih tergolong rendah. Hal ini dapat dilihat dari data hasil ujian tengah semester yang diambil pada saat observasi.

Berdasarkan observasi yang dilakukan, didapat data capaian hasil belajar peserta didik kelas VI A yang tuntas sebanyak 11 orang (45,83\%), sedang yang tidak tuntas sebanyak 13 orang $(54,17 \%)$ dan peserta didik kelas VI B yang tuntas sebanyak 11 orang $(47,83 \%)$, sedang yang tidak tuntas sebanyak 12 orang $(52,17 \%)$. Data tersebut membuktikan bahwa hasil belajar kelas VI di salah satu SD Negeri yang terdapat di Kecamatan Bakauheni masih tergolong rendah.

Slameto (2013:45) menyatakan dalam mencapai keberhasilan dalam pembelajaran banyak faktor yang mempengaruhinya, yaitu faktor internal dan faktor eksternal. Faktor internal adalah faktor yang berasal dari dalam diri peserta didik yaitu contohnya minat, bakat, dan motivasi belajar. Sedangkan faktor eksternal adalah faktor yang berasal dari luar diri peserta didik yaitu berupa pengaruh dari lingkungan belajar.

Minat belajar adalah ketertarikan atau kecenderungan yang tetap untuk memperhatikan atau terlibat terhadap sesuatu hal karena menyadari pentingnya hal tersebut. Hasil pengamatan sementara terhadap peserta didik kelas VI di salah satu SD Negeri yang terdapat di Kecamatan Bakauheni dapat dinyatakan bahwa minat belajar peserta didik masih tergolong rendah. Hal ini terlihat pada saat proses pembelajaran 
berlangsung sebagian peserta didik sering mengantuk, tertidur di kelas dan berbicara sendiri dengan temannya, tentunya ini mengganggu peserta didik lain yang ingin memperhatikan.

Selain minat belajar, faktor lainnya yang mempengaruhi hasil belajar adalah motivasi belajar. Motivasi merupakan suatu pendorong yang mengubah energi dalam diri seseorang kedalam bentuk aktivitas nyata untuk mencapai tujuan tertentu. Shabani (2012: 321) menganggap motivasi belajar sebagai keyakinan yang melekat untuk membimbing individu dalam mencapai tujuan pembelajaran, mendorong perilaku belajar supaya berkelanjutan, memperkuat pengetahuan, dan meningkatkan hasil belajar.

Hasil pengamatan sementara didapatkan bahwa peserta didik kelas VI di salah satu SD Negeri yang terdapat di Kecamatan Bakauheni memiliki motivasi belajar yang rendah hal ini terlihat dari beberapa peserta didik yang cenderung pasif dalam menerima penjelasan dari pendidik. Selain itu, dalam mengerjakan tugas yang diberikan, ketika peserta didik tersebut mendapatkan soal yang sulit mereka mudah putus asa, hasilnya mereka mengerjakan tugas tersebut seadanya, menunda mengumpulkan tugas bahkan tidak mengumpulkan tugas sama sekali.

Kenyataan lain menunjukkan pendidik dalam proses pembelajaran hanya memberikan materi pembelajaran saja, jarang sekali memberikan motivasi pada peserta didik dalam mengajar. Hal ini disebabkan banyaknya jumlah pokok bahasan yang harus diajarkan sehingga pendidik cenderung hanya memberikan materi saja tanpa berusaha membangkitkan motivasi belajar peserta didik. 
Faktor lainnya yang mempengaruhi hasil belajar peserta didik adalah lingkungan belajar tempat tinggal. Seperti yang dijelaskan oleh Sumiati (2012: 4) bahwa lingkungan belajar tempat tinggal tidak hanya secara langsung mempengaruhi tinggi rendahnya hasil belajar, tetapi juga akan menyentuh ranah kognitif atau personal peserta didik yang tentunya hal ini berpengaruh pada kehidupannya dimasa mendatang.

Lingkungan belajar tempat tinggal merupakan suatu komponen yang ikut menentukan keberhasilan proses pembelajaran. Bakauheni merupakan daerah yang terletak di ujung bagian Selatan pulau Sumatera, yang beberapa tempat tinggalnya berbentuk panggung dan terbuat dari kayu. Hal ini memudahkan agar ketika air pasang datang, air tersebut tidak langsung masuk ke rumah.

Akan tetapi, rumah yang terbuat dari kayu akan lebih mudah menerima suara-suara dari luar. Lingkungan belajar tempat tinggal peserta didik yang berdekatan dengan jalan raya, pasar dan pelabuhan tentu saja menganggu proses belajar mereka. Suara bising kendaraan yang lewat dapat menyebakan sulitnya peserta didik memperoleh fokus saat belajar. Sehubungan dengan permasalahan tersebut peneliti tertarik untuk melakukan penelitian mengenai "Pengaruh Lingkungan Tempat Tinggan dan Motivasi Belajar terhadap Hasil Belajar Peserta Didik Kelas VI di SD Negeri 1 Bakauheni”.

\section{METODE}

Penelitian ini termasuk penelitian ex-post-facto, karena penelitian ini untuk meneliti keadaan yang telah terjadi kemudian merunut kebelakang untuk mengetahui faktor-faktor yang menyebabkan timbulnya kejadian tersebut. Pendekatan yang digunakan adalah pendekatan kuantitatif. Pendekatan kuantitatif digunakan untuk mengukur variabel bebas dan variabel terikat dengan menggunakan angka-angka yang diolah melalui analisis statistik. Penelitian ini untuk menguji hipotesis yang digunakan, 
oleh karena itu penelitian ini bertujuan untuk mengetahui hubungan antar variabel lingkungan tempat tinggal (X1) dan motivasi belajar (X2) terhadap variabel hasil belajar (Y) peserta didik kelas VI SD Negeri 1 Bakauheni.

Prosedur penelitian merupakan langkah-langkah yang ditempuh dalam penelitian. Tahap-tahap dalam penelitian ini adalah 1) Memilih subjek penelitian yaitu peserta didik kelas VI SD Negeri 1 Bakauheni. Subjek uji coba instrumen kuisioner (angket) yaitu 15 orang peserta didik yang bukan bagian dari subjek penelitian. 2) Menyusun kisi-kisi dan instrumen pengumpulan data berupa angket. 3) Menguji coba instrumen pengumpul data pada subjek uji coba angket. 4) Menganalisis data dari hasil uji coba instrumen untuk mengetahui apakah angket yang telah dibuat telah valid dan reliabel. 5) Melaksanakan penelitian dengan membagikan angket kepada sampel penelitian. Selanjutnya untuk mengetahui hasil pelajar peserta didik, peneliti menggunakan studi dokumentasi yang dilihat pada dokumen hasil penilaian tengah semester kelas VI SD Negeri 1 Bakauheni tahun pelajaran 2020/2021. 6) Menghitung kedua data yang diperoleh untuk mengetahui pengaruh lingkungan tempat tinggal dan motivasi belajar terhadap hasil belajar peserta didik kelas VI SD Negeri 1 Bakauheni. 7) Interpretasi hasil perhitungan data.

Objek penelitian ini adalah peserta didik kelas VI A dan VI B SD Negeri1 Bakauheni. Subjek penelitian ini berjumlah 47 peserta didik. Penelitian ini dilaksanakan tahun pelajaran 2020/2021. Penelitian ini dilaksanakan di SD Negeri 1 Bakauheni, Kecamatan Bakauheni, Kabupaten Lampung Selatan, Provinsi Lampung Selatan.

Populasi dalam penelitian ini adalah kelas VI SD Negeri 1 Bakauheni yang berjumlah 47 peserta didik yang terdiri dari 22 peserta didik laki-laki dan 29 peserta didik perempuan. Teknik pengambilan sampel dalam penelitian ini menggunakan teknik 
non probability sampling. Arikunto (2013: 71) menjelaskan jika populasi kurang dari 100 lebih baik diambil sebagai penelitian populasi. Karena sedikitnya jumlah populasi maka peneliti menggunakan metode total sampling yakni seluruh populasi menjadi anggota yang akan dianalisis sebagai sampel. Dalam penelitian ini yang menjadi sampel adalah 47 peserta didik.

Penelitian ini terdiri dari dua variabel, yaitu variabel bebas (independent variable) dan variabel terikat (dependent variable). Menurut Sugiyono (2013: 38) menyatakan bahwa variabel adalah suatu atribut, sifat, nilai dari orang, objek atau kegiatan yang mempunyai variasi yang ditetapkan oleh peneliti untuk dipelajari dan kemudian ditarik kesimpulan. Variabel bebas pada penelitian ini adalah lingkungan tempat tinggal (X1) dan motivasi belajar (X2). Sedangkan variabel terikat pada penelitian ini adalah hasil belajar (Y).

Teknik pengumpulan data merupakan langkah yang paling utama dalam penelitian. Karena tujuan utama penelitian adalah mendapatkan data. Teknik pengumpulan data yang digunakan dalam penelitian ini adalah kussioner/angket dan studi dokumentasi. Sugiyono (2013: 144) menyatakan bahwa angket merupakan teknik pengumpulan data yang dilakukan dengan cara memberi seperangkat pertanyaan atau pernyataan tertulis kepada responden untuk dijawab. Angket ini diberikan kepada peserta didik untuk memperoleh informasi mengenai lingkungan tempat tinggal dan motivasi belajar peserta didik. Kuesioner (angket) ini dibuat dengan model Likert dengan empat alternatif jawaban untuk setiap pertanyaan yang diajukan. Sedangkan studi dokumentasi dalam penelitian ini berupa data jumlah peserta didik dan hasil belajar peserta didik kelas VI SD Negeri 1 Bakauheni tahun ajaran 2020/2021. 
Instrumen yang baik harus memenuhi dua persyaratan penting, yaitu valid dan reliabel. Dalam upaya untuk memperoleh keakuratan data yang dikumpulkan, maka hasil uji coba instrumen penelitian ini perlu diuji keakuratannya dengan menggunakan uji validitas dan uji relaibilitas.. Uji validitas intrumen digunakan untuk mengetahui kesahihan butir pertanyaan dan pernyataan, sehingga data yang digunakan dalam analisis selanjutnya merupakan data yang dianbil dari butir pernyataan yang valid, sedangkan butir pernyataan yang tidak valid diperbaiki agar tetap mewakili secara representatif apa yang diukur. Validitas instrumen kuesioner (angket) ini dilakukan dengan menggunakan validitas isi dan konstruk. Validitas isi merupakan validitas yang ditilik dari segi instrumen sebagai alat pengukur, sedangkan validitas konstruk merupakan validitas yang ditinjau dari segi susunan, kerangka atau rekaannya instrumen kuesioner tersebut. Untuk uji validitas konstruk menggunakan teknik expert judgement, dalam hal ini validitas konstruk dilakukan oleh salah satu dosen PGSD FKIP Unila Bapak Ismu Sukamto, M.Pd. Setelah melakukan validitas konstruk, peneliti melakukan uji validiats butir angket. Pengujian validitas instrumen menggunakan rumus korelasi Product Momen. Sedangkan instrumen dikatakan variabel jika instrumen tersebut digunakan beberapa kali mengukur objek yang sama, akan menghasilkan data yang sama. Untuk mengukur tingkat realibilitas penelitian ini menggunakan rumus Alpha Cronbach karena pemberian skor untuk instrumen lingkungan tempat tinggal dan motivasi belajar adalah 1 sampai dengan 4 . Teknik analisis data yang digunakan dalam penelitian ini adalah uji prasyarat yang terdiri dari uji normalitas dan uji linearitas serta uji hipotesis. 


\section{HASIL DAN PEMBAHASAN}

SD Negeri 1 Bakauheni beralamatkan di Jl. Pariwisata Tanjung Tua Simpang Tiga, Desa Bakauheni, Kecamatan Bakauheni, Kabupaten Lampung Selatan, Provinsi Lampung. SD Negeri 1 Bakauheni memiliki sarana dan prasarana yang menunjang proses pembelajaran dengan rincian:10 ruang kelas, 1 ruang guru, 4 toilet, 1 gudang, 1 UKS, 1 perpustakaan, 1 dapur, 1 kantin, dan tempat parkir. SD Negeri 1 Bakauheni memiliki jumlah peserta didik kelas I-VI tahun ajaran 2020/2021 sebanyak 368 peserta didik. SD Negeri 1 Bakauheni berdiri pada tahun 1977 dan telah mengalami beberapa pergantian kepala sekolah. Kepala sekolah saat ini adalah Ibu Rostina, S.Pd.SD. Pendidik dan tenaga kependidikan berjumlah 16 orang.

\section{Data Variabel Penelitian}

Deskripsi data variabel bertujuan untuk menjelaskan variabel atau hasil data dalam ruang lingkup terbatas. Berdasarkan hasil penelitian tentang lingkungan tempat tinggal (X1) dan motivasi belajar (X2) terhadap hasil belajar peserta didik (Y) yang dilakukan pada kelas VI SD Negeri 1 Bakauheni dengan jumlah responden yaitu 47 orang. Selanjutnya data hasil belajar peserta didik diambil dari nilai penilaian tengah semester genap matematika tahun ajaran 2020/2021.

Data variabel lingkungan tempat tinggal diperoleh dari hasil jawaban angket peserta didik yang berjumlah 24 pertanyaan. Hasil uji validitas diperoleh 14 pertanyaan yang valid dan akan digunakan dalam penelitian. Tabel 1 akan memperlihatkan hasil penelitian tentang lingkungan tempat tinggal dengan 47 orang responden.

Tabel 1. Distribusi Frekuensi Variabel X1

\begin{tabular}{rrcccc}
\hline No & Kelas Interval & $\mathbf{f i}$ & $\mathbf{X i}$ & $\mathbf{F i . x i}$ & Persentase (\%) \\
\hline 1 & $32-34$ & 6 & 33 & 198 & 13 \\
2 & $35-37$ & 8 & 36 & 288 & 17 \\
3 & $38-40$ & 10 & 39 & 390 & 21 \\
4 & $41-43$ & 9 & 42 & 378 & 19 \\
5 & $44-46$ & 6 & 45 & 270 & 13 \\
6 & $47-49$ & 6 & 48 & 288 & 13
\end{tabular}




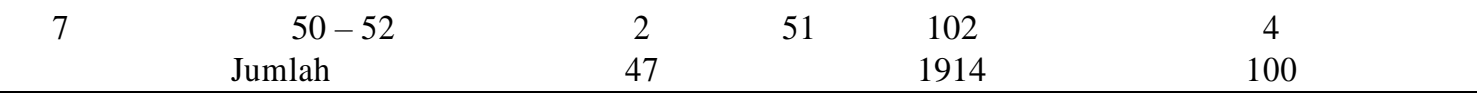

Berdasarkan tabel di atas, menunjukkan bahwa lingkungan tempat tinggal terdapat dibawah rata-rata sebanyak 24 dari 47 peserta didik. Hal ini menunjukkan bahwa lingkungan tempat tinggal peserta didik kelas VI SD Negeri 1 Bakauheni tergolong rendah.

Data variabel motivasi belajar diperoleh dari hasil jawaban angket peserta didik yang berjumlah 24 pertanyaan. Hasil uji validitas diperoleh 13 pertanyaan yang valid dan akan digunakan dalam penelitian. Tabel 2 akan memperlihatkan hasil penelitian tentang motivasi belajar dengan 47 orang responden.

Tabel 2. Distribusi Frekuensi Variabel $\mathrm{X}_{2}$

\begin{tabular}{rccccc}
\hline No & Kelas Interval & Fi & Xi & Fi.xi & Persentase (\%) \\
\hline 1 & $29-31$ & 8 & 30 & 240 & 17 \\
2 & $32-34$ & 9 & 33 & 297 & 19 \\
3 & $35-37$ & 10 & 36 & 360 & 21 \\
4 & $38-40$ & 6 & 39 & 234 & 13 \\
5 & $41-43$ & 7 & 42 & 294 & 15 \\
6 & $44-46$ & 5 & 45 & 225 & 4 \\
7 & $47-49$ & 2 & 48 & 96 & 100 \\
\hline
\end{tabular}

Berdasarkan tabel di atas, menunjukkan bahwa motivasi belajar terdapat dibawah rata-rata sebanyak 27 dari 47 peserta didik. Hal ini menunjukkan bahwa motivasi belajar peserta didik kelas VI SD Negeri1 Bakauheni tergolong rendah.

Data variabel hasil belajar diperoleh dari penilaian tengah semester ganjil mata pelajaran matematika tahun ajaran 2020/2021. Tabel 3 akan memperlihatkan hasil penelitian penelitian tentang hasil belajar dengan 47 peserta didik.

Tabel 3. Distribusi Frekuensi Variabel Y

\begin{tabular}{rccccc}
\hline No & Kelas Interval & Fi & Xi & fi.xi & Persentase (\%) \\
\hline 1 & $55-59$ & 6 & 57 & 342 & 13 \\
2 & $60-64$ & 10 & 62 & 620 & 21 \\
3 & $65-69$ & 9 & 67 & 603 & 19 \\
4 & $70-74$ & 8 & 72 & 576 & 17 \\
5 & $75-79$ & 7 & 77 & 539 & 15 \\
6 & $80-84$ & 4 & 82 & 328 & 9
\end{tabular}




\begin{tabular}{cccccc}
7 & $85-89$ & 3 & 87 & 261 & 6 \\
& Jumlah & 47 & & 3269 & 100 \\
\hline & Berdasarkan tabel di atas, menunjukkan bahwa lingkungan tempat tinggal terdapat
\end{tabular}
dibawah rata-rata sebanyak 25 dari 47 peserta didik. Hal ini menunjukkan bahwa hasil belajar peserta didik kelas VI SD Negeri 1 Bakauheni tergolong rendah.

\section{Hasil Analisis Data Penelitian}

Uji normalitas dilakukan untuk mengetahui apakah data yang dianalisis mempunyai sebaran (berdistribusi) normal atau tidak. Terdapat tiga data yang perlu diuji normalitaskan, yaitu data lingkungan tempat tinggal, motivasi belajar dan hasil belajar. Uji normalitas menggunakan rumus uji Chi Kuadrat secara manual dengan bantuan program Microsoft Office Excel 2007. Interpretasi perhitungan data lingkungan tempat tinggal dilakukan dengan membandingkan X2 hitung dengan X2 tabel untuk $\alpha=$ 0,05 dengan $\mathrm{dk}=\mathrm{dk}-1=7-1=6$ didapat tabel chi kuadrat X2 tabel sebesar 12,592. Sesuai kaidah yang menyatakan bahwa X2 hitung $=3,120<\mathrm{X} 2$ tabel $=12,592$, berarti data variabel $\mathrm{X} 1$ berdistribusi normal.

Interpretasi perhitungan data motivsai belajar dilakukan dengan membandingkan $\mathrm{X} 2$ hitung dengan $\mathrm{X} 2$ tabel untuk $\alpha=0,05$ dengan $\mathrm{dk}=\mathrm{dk}-1=7-1=6$ didapat tabel chi kuadrat X2 tabel sebesar 12,592. Sesuai kaidah yang menyatakan bahwa X2 hitung $=6,274<\mathrm{X} 2$ tabel $=12,592$, berarti data variabel $\mathrm{X} 2$ berdistribusi normal .

Interpretasi perhitungan data hasil belajar dilakukan dengan membandingkan X2 hitung dengan X2 tabel untuk $\alpha=0,05$ dengan $\mathrm{dk}=\mathrm{dk}-1=7-1=6$ didapat tabel chi kuadrat X2 tabel sebesar 12,592. Sesuai kaidah yang menyatakan bahwa X2 hitung = $3,820<\mathrm{X} 2$ tabel $=12,592$, berarti data variabel $\mathrm{Y}$ berdistribusi normal .

Hasil uji linearitas pada variabel X1 dan Y yaitu dk pembilang $(\mathrm{k}-2)=18-2=$ 16 dan dk penyebut $(\mathrm{n}-\mathrm{k})=47-18=29$ dengan $\alpha=0,5 \%$ maka diperoleh $: \mathrm{F}_{\text {tabel }}=$ 
2,01 didapati dengan kaidah yang menyatakan bahwa $F_{\text {hitung }}=1,91<\mathrm{F}_{\text {tabel }}=2,01$ maka data bersifat linier. Hasil uji linearitas pada variabel X2 dan Y yaitu dk pembilang (k $2)=20-2=18$ dan dk penyebut $(\mathrm{n}-\mathrm{k})=47-20=27$ dengan $\alpha=0,5 \%$ maka diperoleh : $\mathrm{F}_{\text {tabel }}=2,00$ didapati dengan kaidah yang menyatakan bahwa $\mathrm{F}_{\text {hitung }}=1,28<\mathrm{F}_{\text {tabel }}=$ 2,00 maka data bersifat linier.

Setelah dilakukan uji normalitas dan linieritas diperoleh data berdistribusi normal dan linier, selanjutnya dilakukan uji hipotesis. Hasil uji hipotesis pertama dengan $\alpha=$ 0,05 dan $\mathrm{df}=\mathrm{n}-\mathrm{k}-1=28-2=26$ diperoleh bahwa: $\mathrm{t}_{\text {tabel }}=2,014$ dengan kriteria nilai $t_{\text {hitung }}=1<$ nilai $t_{\text {tabel }}=2,014$ maka Ho diterima, Ha ditolak. Dengan demikian tidak ada pengaruh variabel $\mathrm{X} 1$ terhadap $\mathrm{Y}$. Jadi, dapat disimpulkan bahwa tidak ada pengaruh lingkungan tempat tinggal terhadap hasil belajar peserta didik kelas VI di SD Negeri 1 Bakauheni.

Hasil uji hipotesis kedua dengan $\alpha=0,05$ dan df $=\mathrm{n}-\mathrm{k}-1=28-2=26$ diperoleh bahwa: $t_{\text {tabel }}=2,014$ dengan kriteria nilai $t_{\text {hitung }}=3,552<$ nilai $t_{\text {tabel }}=2,014$ maka Ha diterima, Ho ditolak. Dengan demikian ada pengaruh variabel X2 terhadap Y. Jadi, dapat disimpulkan bahwa ada pengaruh motivasi belajar terhadap hasil belajar peserta didik kelas VI di SD Negeri 1 Bakauheni.

\section{Pengaruh Lingkungan Tempat Tinggal Terhadap Hasil Belajar Peserta Didik}

Berdasarkan hasil analisis untuk hipotesis pertama menggunakan bantuan Microsoft Excel 2016 diperoleh nilai koefisien korelasi (r) sebesar 0,15 dan koefisien determinasi (r2) sebesar $2,25 \%$ serta hasil uji analisis regresi sederhana diperoleh nilai $t_{\text {hitung }} 1$ lebih kecil dari nilai $t_{\text {tabel }}$ 2,014. Dengan demikian tidak ada pengaruh lingkungan tempat tinggal terhadap hasil belajar peserta didik kelas VI SD N 1 Bakauheni. 
Penelitian tersebut bertolak belakang dengan pendapat Sumiati (2012: 4) yang menyatakan bahwa lingkungan belajar tempat tinggal tidak hanya secara langsung mempengaruhi tinggi rendahnya hasil belajar, tetapi juga akan menyentuh ranah kognitif atau personal peserta didik yang tentunya hal ini berpengaruh pada kehidupannya dimasa mendatang.

Sukmadinata dan Syaodih (2012: 199) menyatakan bahwa lingkungan belajar tempat tinggal adalah lingkungan belajar yang mempengaruhi hasil belajar peserta didik, meliputi: ruangan tempat siswa belajar, meubiler yang digunakan, lampu/cahaya dan ventilasi, serta suasana sekitarnya.

\section{Pengaruh Motivasi Belajar Terhadap Hasil Belajar Peserta Didik}

Berdasarkan hasil analisis untuk hipotesis pertama menggunakan bantuan Microsoft Excel 2016 diperoleh nilai koefisien korelasi (r) sebesar 0,18 dan koefisien determinasi (r2) sebesar 32,4\% serta hasil uji analisis regresi sederhana diperoleh nilai $t_{\text {hitung }}$ 3,552 lebih besar dari nilai $t_{\text {tabel }}$ 2,014. Dengan demikian ada pengaruh motivasi belajar terhadap hasil belajar peserta didik kelas VI SD N 1 Bakauheni.

Hal ini sejalan dengan pendapat Shabani (2012: 321) yang menganggap motivasi belajar sebagai keyakinan yang melekat untuk membimbing individu dalam mencapai tujuan pembelajaran, mendorong perilaku belajar supaya berkelanjutan, memperkuat pengetahuan, dan meningkatkan hasil belajar.

Berdasarkan analisis tersebut dapat disimpulkan bahwa motivasi memiliki tiga fungsi yaitu, memperjelas tujuan belajar yang hendak dicapai, mendorong timbulnya suatu perbuatan seperti belajar dan menentukan perbuatan yang harus dikerjakan dengan menyisihkan perbuatan yang tidak berguna demi mencapai tujuan yang diinginkan. 


\section{SIMPULAN}

Berdasarkan hasil penelitian dan pembahasan tentang pengaruh lingkungan tempat tinggal dan motivasi belajar terhadap hasil belajar peserta didik kelas VI di SD Negeri 1 Bakauheni, maka dapat disimpulkan bahwa tidak ada pengaruh lingkungan tempat tinggal terhadap hasil belajar peserta didik kelas VI SD Negeri 1 Bakauheni, diperoleh $t_{\text {hitung }}=1<$ nilai $t_{\text {tabel }}=2,014$ dengan koefisien korelasi $(r)$ 0,15 dan koefisien determinasi (r2) 2,25\%. Ada pengaruh motivasi belajar terhadap hasil belajar peserta didik kelas VI SD Negeri 1 Bakauheni, diperoleh $t_{\text {hitung }}=3,552>$ nilai $t_{\text {tabel }}=2,014$ dengan koefisien korelasi (r) 0,18 dan koefisien determinasi (r2) 32,4\%.

\section{DAFTAR PUSTAKA}

Arikunto, Suharsimi. 2013. Posedur Penelitian Suatu Pendekatan Praktik. Jakarta: PT.Rineka Cipta.

Jude, L. T., Kajura, M. A., \& Birevu, M. P. 2014. Adoption of the SAMR model to asses ICT pedagogical adoption: A case of Makerere University. International Journal of e-Education, e-Business, e-Management and e-Learning, 4(2), 106.

Meidinasari, C., Sabdaningtyas, L., \& Sugiman, S. 2019. Pengaruh Lingkungan Belajar di Sekolah dan Motivasi Belajar terhadap Hasil Belajar. Jurnal Pedagogi, 2(4).

Shabani, K. 2012. Dynamic assessment of L2 learners' reading comprehension processes: A Vygotskian perspective. Procedia-Social and Behavioral Sciences, 32, 321-328.

Slameto. 2013. Belajar dan Faktor-Faktor yang Mempengaruhinya. Jakarta: PT Rineka Cipta.

Sugiyono. 2013. Meotode Penelitian Pendidikan Pendekatan Kuantitatif, Kualitatif, dan $R \& D$. Bandung: Alfabet.

Sukmadinata, N. S., \& Syaodih, E. 2012. Kurikulum dan Pembelajaran Kompetensi. Bandung: PT. Refika Aditama.

Sumiati. 2012. Pengaruh Lingkungan Belajar Siswa Terhadap Motivasi Belajar dan Implikasinya terhadap Hasil Belajar Siswa Pada Mata Pelajaran Ekonomi Syariah di SMP Kota Tasikmalaya. Jurnal Pendidikan Ekonomi dan Koperasi, Vol. 7, No. 1. 